\title{
Do Public-Private Partnerships Improve the Operational Efficiency of Infrastructure in Mainland China?
}

\author{
Haicheng Xu, ${ }^{1,2}$ Xiao Wei $\mathbb{D}^{1,2}{ }^{1,2}$ Bo Wang, ${ }^{1,2}$ Yan Cheng, ${ }^{1,2}$ and Yijiao Wang ${ }^{3}$ \\ ${ }^{1}$ School of Economics and Management, Chang'an University, Xi'an 710064, China \\ ${ }^{2}$ Research Center of Economics and Management for Highway Infrastructure, Chang'an University, Xi'an 710064, China \\ ${ }^{3}$ College of Transportation Engineering, Chang'an University, Xi'an 710064, China
}

Correspondence should be addressed to Xiao Wei; weixiao@chd.edu.cn

Received 22 August 2020; Revised 21 October 2020; Accepted 31 October 2020; Published 19 November 2020

Academic Editor: Mehmet Serkan Kirgiz

Copyright $\odot 2020$ Haicheng Xu et al. This is an open access article distributed under the Creative Commons Attribution License, which permits unrestricted use, distribution, and reproduction in any medium, provided the original work is properly cited.

Public-private partnerships (PPPs) are widely used to achieve sustainable infrastructure provision. The purpose of this research is to monitor the effects of PPPs in practice. This study calculated the operational efficiency of toll roads in Mainland China and examined the effect of the transformation from government operations to concession on their operational efficiency. The results showed that toll road operations were inefficient in terms of cost savings and that there were significant regional differences in the impact of concession on operational efficiency among three regions. Concession played a positive role in improving the operational efficiency in the eastern region; on the contrary, the influence was significantly negative in the western region. The effect on the central region was not significant. The results indicated that the efficiency advantages of concession were not given full play. The governments of economies in transition should pay more attention to the implementation environment of PPPs to make infrastructure operations more sustainable.

\section{Introduction}

Infrastructure provision is critical to transport, and reliable and high-quality transport services depend to a large extent on the support of sustainable infrastructure. In recent years, developing countries have vigorously promoted the application of PPP systems in the field of infrastructure provision $[1,2]$. Private capital can offset a shortfall in government finance to meet the increasing demand for infrastructure construction [3], and full play should be given to its advantages in technology and operations. Additionally, the government is responsible for planning and regulation to achieve the effect of " $1+1>2$ " [4]. Theoretically, PPPs are used to improve the quality and efficiency of infrastructure provision [5]. Better services, lower costs, and optimum efficiency are the promises made by politicians and private investors [6]. However, private participation may result in corruption, rent-seeking, new private monopolies, and other problems [3, 7-9], which may affect the provision efficiency [10]. While they may satisfy financial needs, the impact of
PPPs on the provision efficiency of infrastructure deserves our attention.

Concession has been increasingly implemented in toll road projects [11]. Since 2014, the proportion of the mileage of concessionary toll roads to the total length of toll roads has increased rapidly in Mainland China (as shown in Figure 1). China's central government has issued a series of policies to promote the application of PPPs in toll roads [12]. By the end of 2019, China had 168,100 kilometres of toll roads that operated using one of two modes [13]. One mode is that the public sector is in charge of toll road operation under a strict budgetary system of revenues and expenditures. The other mode refers to concession, in which private firms obtain the operating rights of toll roads by investing in their construction or by bidding. Empirically evaluating the impact of concession on the operational efficiency of China's toll roads not only provides a Chinese case for monitoring the effects of a PPP system but also contributes to improving the sustainability of PPPs in the field of public facilities and infrastructure over the entire life cycle. 


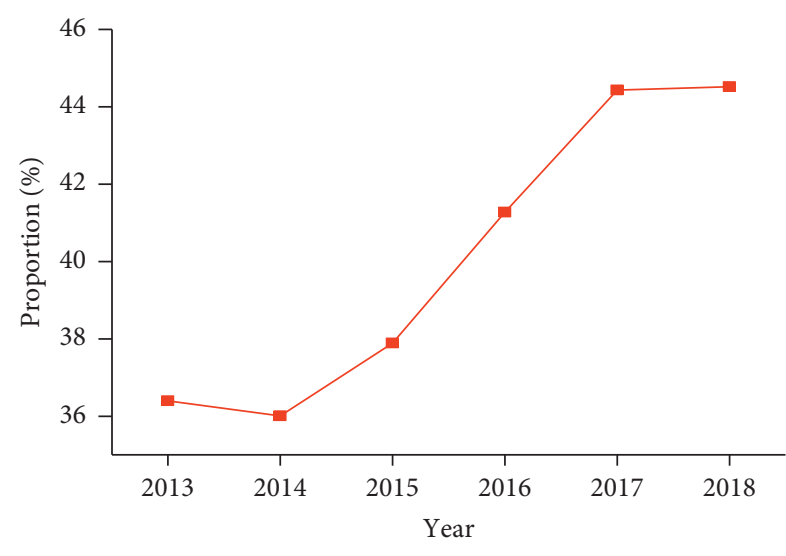

Figure 1: The proportion of the mileage of concessionary toll roads to the total length of toll roads.

There are two kinds of research streams concentrating on the relationship between the provision systems and the performance of toll roads. The first stream focuses on the problems generated in the operating process by public authorities, such as administrative monopolies [14], regulatory failures [15], rent dissipation [16], and diseconomies of scale [17]. Some researchers have explained why and how these factors affect the operational efficiency of toll roads and regard concession as the direction for the operational reform of toll roads $[18,19]$. The second stream focuses on the operational efficiency of concessionary toll roads. This research has evaluated the efficiency of China's expressway companies and compared the operational efficiency of toll roads under different operating modes, concluding that the concession system is more efficient at operating toll roads than public authorities $[20,21]$. However, existing evidence supporting the efficiency advantages of concession is inadequate. Research has failed to consider the differences in other factors influencing operational efficiency.

To fill this gap, we evaluated the operational efficiency of toll roads including concessionary and public ownership based on samples of 29 provinces in Mainland China. Then, we constructed a regression model that controlled other influential factors to investigate the impact of the transformation from government operations to concession on the operational efficiency of toll roads. Considering the regional differences, this research divided the 29 provinces into eastern, central, and western regions to formulate the results.

This research makes the following two contributions. First, we constructed an empirical model that controlled the possible factors affecting the operational efficiency of toll roads, including the institutional environment, economic development, competition, and scale. Second, the impact of concession on the operational efficiency of toll roads was examined at national and regional levels using the empirical model. The results provide an empirical basis for monitoring the effects of a PPP system and improving the sustainability of PPPs in the field of public facilities and infrastructure over the entire life cycle.

The remainder of this paper is organized as follows. Section 2 reviews the performance of PPPs and their evaluation methods. Section 3 presents the methods and variables adopted in this research. Section 4 provides the results of the efficiency calculation and regression. The important findings are further discussed in Section 5. The final section draws the main conclusion and puts forwards several policy implications. The limitations of this research are also included.

\section{Literature Review}

2.1. The Performance of PPPs. In recent decades, PPPs have been very popular in the field of infrastructure provision. Houdge et al. believed that PPP performance has attracted the attention of many scholars and is a major direction of future research [22]. Jeffares et al. stressed that PPP performance depends on the extent to which PPPs help the government to achieve its desired goals [23]. Jie deemed that the main motivations for the Chinese government to adopt PPPs are efficiency, financing, and governance. Accordingly, PPP performance is also measured from three aspects, that is, whether the PPP improves the supply efficiency, whether the PPP effectively introduces private capital, and whether the PPP improves the governance capacity of the government [24]. Although the implementation of PPPs in developing countries at present is mainly driven by capital demand, efficiency is the essence of the sustainable supply of infrastructure throughout its life cycle, and it is also the main topic discussed by scholars [1]. Shouqing et al. divided the life cycle of PPP projects into four stages: preparation, construction, operation, and transfer [25]. Since the financing costs are generally higher for PPP projects than other projects [26], the relative operational and delivery efficiency are major determinants of the value for money of PPP projects [27]. In addition, the Ministry of Finance of China also requires that operational efficiency should be regarded as the core index of pay-for-performance [28]. Therefore, this paper focused on PPP performance in terms of operational efficiency.

Regarding the criteria of successful PPPs, government officials and scholars have considered PPP performance from different dimensions and perspectives [29]. The measures of the success of PPPs include cost, quality, schedule [30, 31], stability assurance [32], and social welfare [33]. For example, Wang et al. surveyed existing studies and found that PPP performance often cooccurs with the keywords value for money (VFM), cost, public value, and benefits [34]. Helby reviewed the costs, quality, and VFM of infrastructure PPPs [35]. Under a certain economic downward pressure, China is faced with the dual challenge of lowering tolls and improving infrastructure supply [36]. In 2018, the gap between the toll revenues and total expenditures on China's toll roads had reached 406.94 billion yuan [13]. The World Bank stated that cutting costs and improving productivity efficiency are the best ways to reduce this gap [37]. It is evident that improving operational efficiency and reducing operating costs are important paths for the sustainable development of infrastructure.

In summary, this paper aims to provide empirical evidence of the infrastructure delivery mode for public administration departments in this industry. As a result, PPP 
performance in this research refers to whether PPPs can improve operational efficiency compared with the traditional public operation, which eventually reduce the infrastructure operating costs. Accordingly, we defined the operational efficiency of infrastructure in terms of costs, that is, the ability of project companies to minimize operating costs when a certain amount of infrastructure is operated or the ability to maximize the number of infrastructures operating at the given operating costs.

2.2. The Evaluation Methods of PPP Performance. Based on the PPP performance defined in this paper, the typical evaluation methods of PPP performance are case studies, surveys, statistical analysis, and econometric analysis $[22,38]$. For example, Cai adopted 13 cases to analyse the institutional performance of institutional arrangements [32]. Chasey et al. surveyed the cost and schedule overrun data for 12 highway projects procured under PPPs and compared them with the statistics of projects completed through traditional public procurement [39]. Helby stated that the comparability between the treatment group and the control group is crucial [35]. Chen et al. and Raisbeck et al. argued that the case descriptions and small- $N$ studies were too naive to be generalizable, and the investigation results were not sufficient $[31,40]$. Nevertheless, these methods have been widely used and are generally attributed to the limited availability of PPP data. Tan and Zhao stated that large- $N$ studies can be conducted to examine many hypotheses, such as those related to the adoption, implementation, and performance of PPPs [1]. Vis $\mathrm{B}$. argued that an advantage of a moderately large $-N$ is that it allows one to explain the variation in outcome using regression analysis [41]. Blanc-Brude et al. employed regression analysis to compare the ex ante construction costs of infrastructure between PPPs and traditional public procurement [42].

China's PPP experiments on toll roads and the large amount of public data provide the opportunity to systematically study the PPP performance of infrastructure. China's toll roads adopt such a management system: the Ministry of Transport of China is only responsible for formulating policies and regulations for road development planning, construction, toll collection, and other aspects, while provincial governments are specifically responsible for the financing, operation, and management of roads within provinces [43]. Therefore, vastly diversified supply modes for toll roads exist across the 31 provinces. Since 2013, the Ministry of Transport of China has released an annual statistical bulletin on the toll roads of all provinces. In addition to Tianjin, Chongqing, and Liaoning provinces, which have only concessionary roads, 26 provinces have both concessionary roads and government-operation roads (Hainan and Tibet have no toll road) [13].

This research uses regression analysis to examine the hypothesis that PPPs improve the operational efficiency of toll roads in Mainland China. The regression analysis has the following two advantages: (i) It can test whether an individual variable has a positive or negative significant effect on the outcome and estimate the net effect [41].

(ii) It is the most effective method to control for different factors that may affect the outcome [44]. Consequently, regression analysis is a suitable method to address the problem in this research.

\section{Materials and Methods}

\subsection{Methods}

3.1.1. SBM Model. As a nonparametric performance evaluation method, Slacks-Based Measure (SBM) model has been widely used in the evaluation of the operational efficiency of toll roads and other infrastructures [21]. The SBM model takes the slack variable into account in the objective function and overcomes the deficiency of the traditional DEA model's radial distance function and its measurement results closer to reality [45]. Therefore, this paper still adopted the SBM model to calculate the operational efficiency of toll roads in Mainland China. As an important type of infrastructure, toll roads are designed according to national infrastructure development planning. Thus, the inputoriented SBM model is appropriate. Compared with the variable returns-to-scale (VRS) model, the constant returnsto-scale (CRS) model can reduce systematic deviations. When the calculation results of two models are inconsistent, the CRS is better [46]. Therefore, the input-oriented CRS SBM model was adopted to calculate the efficiency of toll roads.

We assumed that there were $n$ decision-making units (DMUs) and that each DMU has $m$ inputs and $s$ outputs, as shown in formula (1). The input-oriented CRS SBM model was constructed following the basic SBM model proposed by Tone [47]:

$$
\min \rho=1-\frac{1}{m} \sum_{i=1}^{m} \frac{s_{i}^{-}}{x_{i k}}
$$

subject to :

$$
\begin{aligned}
& \sum_{j=1}^{n} x_{i j} \lambda_{j}+s^{-}=x_{k} \\
& \sum_{j=1}^{n} y_{i j} \lambda_{j} \geq y_{k} \\
& \lambda, s^{-} \geq 0 \\
& r=1,2, \ldots, s ; \\
& i=1,2, \ldots, m ; \\
& j=1,2, \ldots, n,
\end{aligned}
$$

where $x_{i j}$ represents input $i$ of DMU $j$ and $y_{r j}$ represents output $r$ of DMU $j . \rho$ is the efficiency values; $s^{--}$represents 
the input excesses, which are called slacks; and $\lambda$ represents the weight vector.

3.1.2. Tobit Regression Method. The operational efficiency of toll roads in Mainland China was measured using the SBM model. To investigate the effects of potential factors on the operational efficiency, we employed a regression model. In addition, the operational efficiency is a relative value and ranges from 0 to 1 . For models where the dependent variable is truncated data, using the traditional leastsquares method for parameter estimation will cause bias [48]. The Tobit regression model is applied to analyse this truncation effect. Consequently, the Tobit regression method was employed in this study. This model assumes that $Y_{i}^{*}$ satisfies formula (2):

$$
Y_{i t}^{*}=\beta_{0}+X_{i t} \beta_{i}+\varepsilon_{i t} .
$$

$Y_{i t}$ is defined as formula (3):

$$
Y_{i t}=\max \left(0, Y_{i t}^{*}\right),
$$

where $X_{i t}$ are the explanatory variables, $Y_{i t}^{*}$ are the latent variables, $Y_{i t}$ are the observed dependent variables, $\beta_{0}$ is a constant, $\beta_{i}$ is the parameter of the explanatory variables, and $\varepsilon_{i t}$ is the random error term.

\subsection{Variable Selection}

3.2.1. Selection of the Inputs and Outputs for Measuring the Operational Efficiency of Toll Roads. As mentioned above, this paper attempts to measure the operational efficiency of toll roads from the perspective of cost savings. It assumes that operators operate a certain number of toll roads without considering the difference in operation quality. Operators manage and maintain toll roads to ensure that they are in a good state of repair for passing vehicles. In return, road users pay tolls to operators in accordance with national and local standards. Therefore, considering the service characteristics of toll road operations, this paper selected maintenance costs and operating and management costs as the input variables and the length of toll roads as the output variable. All the inputs and outputs used to measure the operational efficiency of toll roads are shown in Table 1.

(1) Output: toll road mileage in each province. Mileage represents the number of toll roads that operators can ultimately provide through operation management and maintenance that meet certain technical standards and can be used by vehicles. (2) Inputs: maintenance expenditure. This variable is the sum of the expenses for daily minor maintenance of highways (including the salaries of maintenance personnel), major repair projects, preventive maintenance, purchase of maintenance facilities and equipment, maintenance inspection, emergency maintenance, mechanical and electrical system renovation and maintenance, production, and lighting.

Operation and management expenditures: this variable includes, but is not limited to, business, daily management, road administration, and personnel expenses.
3.2.2. Selection of the Factors Affecting Operational Efficiency of Toll Roads. The purpose of this research is to examine the average effect of an operating mode on operational efficiency. Therefore, it is important to identify the important factors influencing the operational efficiency of toll roads. A number of factors affecting the success or failure of projects have been proposed [49]. Chan et al. systematically established a conceptual framework of the critical success factors (CSFs) of construction projects that contained five sets of variables: project-related factors, procurement-related factors, project management factors, project participant-related factors, and external factors [50]. Iyer and Jha focused on the cost performance of projects and discovered the CSFs and other factors that were not conductive. They concluded that coordination among project participants was critical [51]. Chua et al. found that the importance of project characteristics and contractual arrangements was equivalent to the importance of the project manager and the interactive processes among project participants [52]. Yilin and Yaling divided the factors affecting project performance into controllable and uncontrollable factors. Controllable factors included project governance factors and project management factors, while uncontrollable factors included the political environment, economic climate and degree of perfection of the laws, and regulations of the area in which the project is located [53].

Since the object of this paper is the toll road industry rather than a single project, we focused on factors related to procurement and the external environment and did not take into account the differences in the characteristics of the projects and the differences between participants. First, the procurement factor was considered, which was also the explanatory variable of the hypotheses studied in this paper. Whether toll roads are concessionary or operated by the government may have an important impact on operational efficiency [54]. Then, regarding external environmental factors, the political and economic environment are the most important factors. This paper chose the two variables of the institutional environment and the level of economic development. In addition, the effectiveness of bidding in the procurement stage is mainly affected by the institutional environment [55]. Belassi and Tukel argued that competition in the market is also a significant environmental factor. Competition may influence the allocation of product market resources and needs to be classified as CSFs [56]. Finally, scale, as an important feature of a project, is also an essential factor affecting the efficiency of infrastructure operations, since it has significant economies of scale effect $[21,57]$. In summary, the potential factors influencing the operational efficiency of toll roads, including concession, the institutional environment, economic development, competition, and scale, were selected.

Concession. Concession represents the proportion of the mileage of concessionary toll roads to the total length of the toll roads in each province. As toll roads transform from government operated to concession, the changes in competition, choice, and incentive structures may significantly reduce the administrative costs and $x$-inefficiencies. 
TABLE 1: List of outputs and inputs.

\begin{tabular}{lcc}
\hline Variables & Indicator & Data source \\
\hline Output & Toll road mileage in each province & Toll road statistical bulletin \\
Inputs & Maintenance expenditure & Toll road statistical bulletin \\
& Operations management expenditure & Toll road statistical bulletin \\
\hline
\end{tabular}

However, concession may also introduce new contractual risks [32]. Considering the regional differences in China, it is necessary to study the relationship between concession and operational efficiency in the three stated regions separately.

Hypothesis 1. The greater the proportion of the mileage of concessionary toll roads, the higher the operational efficiency of toll roads.

Hypothesis 2. There were significant regional differences in the relationship between the proportion of the mileage of concessionary toll roads and operational efficiency among the eastern region, the central region, and the western region.

Institutional Environment. The institutional environment refers to the institutional factors affecting the operational efficiency of toll roads in a region. Any production process is embedded in a certain institutional environment, which has a significant impact on productivity, particularly in the infrastructure industry, which has strong institutional dependence $[58,59]$. We utilized the regional marketization index published by the National Economic Research Institute, China Reform Foundation, to represent the quality of the institutional environment of each province [60]. The marketization index was measured using five aspects, including the relationship between the government and the market, the development of the non-state-owned economy, the development of the product market, the development of the factor market, and the development of an intermediary organization and laws. When the institutional environment is sound, the operators prefer to provide better service [61]. We hypothesise that the quality of the institutional environment of each province is negatively correlated with the operational efficiency.

Economic Development. This research employed real GDP per capita to indicate the level of economic development of each province. A province with a higher level of economic development is more likely to purchase high-tech equipment, adopt advanced management technology, and attract qualified personnel. These are important factors affecting the management efficiency of toll roads. We hypothesise that the level of regional economic development is positively correlated with the operational efficiency.

Competition. Railways are the main alternative transport infrastructure to roads since they are appropriate for both medium and short-distance transportation. In particular, intercity high-speed rail lines have developed rapidly in China in recent years. The influence of intercity high-speed railways on passenger transport via toll roads has caused wide concern among the managers of toll roads. This research focused on the operating performance of toll roads using cost savings. The stronger the external competition is, the greater the maintenance and operating costs that have to be invested to improve the service quality of toll roads and attract traffic flow. Finally, the operations may become less effective. We used the density of railways to indicate the degree of competition that toll roads face. We hypothesise that competition is negatively correlated with the operational efficiency.

Scale. The scale was represented by the density of toll roads, which is the proportion of toll road mileage to the administrative area of each province. Scale is also a very important influential variable when studying the cost savings of private participation in garbage recycling and other fields. In addition, the marginal costs of operating toll roads are low, and there are significant economies of scale. Therefore, the larger the scale of the toll roads in each region, the greater the economies of scale. We hypothesise that the scale of toll roads in each province is positively correlated with the operational efficiency.

All the variables used to explain operational efficiency are shown in Table 2.

3.3. Data Collection. This research used 29 provinces in Mainland China as samples. Hainan and Tibet provinces are excluded because they have no toll roads. Toll Road Statistical Bulletins of all provinces have been published by the Ministry of Transport since 2013; however, there is a considerable amount of missing data in 2013. Consequently, we obtained the data of 29 provinces from 2014 to 2018 using the data sources shown in Tables 1 and 2.

According to the classification criteria of the National Bureau of Statistics of China, the samples used in this study were classified into three regions: the eastern region (including Beijing, Tianjin, Hebei, Liaoning, Shanghai, Jiangsu, Zhejiang, Fujian, Shandong, and Guangdong), the central region (Shanxi, Jilin, Heilongjiang, Anhui, Jiangxi, Henan, Hubei, and Hunan), and the western region (including Inner Mongolia, Guangxi, Chongqing, Sichuan, Guizhou, Yunnan, Shaanxi, Gansu, Qinghai, Ningxia, and Xinjiang).

Real GDP per capita was deflated using GDP per capita. The statistical descriptions of the variables explaining the operational efficiency are shown in Table 3. The table shows that there are significant differences among the eastern, central, and western regions in all variables. The regional differences indicate that it is necessary to separately examine the effect of concession in the three regions. 
TABle 2: Definition of variables and data sources.

\begin{tabular}{|c|c|c|c|}
\hline Factor & Indicator & Symbol & Data source \\
\hline Concession & $\begin{array}{c}\text { The proportion of the mileage of concessionary toll roads to the total } \\
\text { length of toll roads }\end{array}$ & Concession & Toll road statistical bulletin \\
\hline $\begin{array}{l}\text { Institutional } \\
\text { environment }\end{array}$ & Regional marketization index & IE & $\begin{array}{l}\text { National economic research } \\
\text { institute }\end{array}$ \\
\hline $\begin{array}{l}\text { Economic } \\
\text { development }\end{array}$ & Real GDP per capita & PGDP & Wind database \\
\hline Competition & The density of railway & Competition & Wind database \\
\hline Scale & The density of toll roads & Scale & Wind database \\
\hline
\end{tabular}

TABle 3: Descriptive statistics of variables.

\begin{tabular}{lcccccrrr}
\hline \multirow{2}{*}{ Variable } & \multicolumn{2}{c}{ National } & \multicolumn{2}{c}{ Eastern } & \multicolumn{2}{c}{ Central } & \multicolumn{2}{c}{ Western } \\
& Mean & SD & Mean & SD & Mean & SD & Mean & SD \\
\hline Concession $(-)$ & 0.463 & 0.351 & 0.624 & 0.322 & 0.409 & 0.285 & 0.357 \\
IE (no) & 7.203 & 2.049 & 9.072 & 1.375 & 7.095 & 0.909 & 5.581 \\
PGDP (CNY) & 59323 & 25473 & 85059 & 24142 & 45700 & 7944 & 45802 & 1.723 \\
Competition $\left(\mathrm{km} / \mathrm{km}^{2}\right)$ & 0.028 & 0.020 & 0.045 & 0.024 & 0.026 & 0.006 & 0.014 & 0.008 \\
Scale $\left(\mathrm{km} / \mathrm{km}^{2}\right)$ & 0.037 & 0.024 & 0.059 & 0.025 & 0.030 & 0.009 & 0.021 & 0.013 \\
\hline
\end{tabular}

\section{Results}

4.1. Results of the Efficiency Calculation. This research evaluated the operational efficiency of the toll roads in 29 provinces utilizing the MaxDEA Ultra 7.0 software (Beijing Realworld Software Company, Beijing, China). The results of the operational efficiency formulated by the input-oriented CRS SBM model are shown in Table 4. Figure 2 shows the average efficiency of each province from 2014 to 2018. Moreover, we classified the 29 provinces into three groups, that is, the eastern region, the central region, and the western region.

First, on the whole, the average operational efficiency of the toll roads in Mainland China was 0.376; it seems that the toll road operations were inefficient. Furthermore, we analysed the distribution of the operational efficiency of each province in detail. Figure 2 shows that none of the provinces in the eastern region had an efficiency greater than 0.4 , and the operational efficiency of the provinces in the eastern region, including Beijing, Tianjin, Hebei, Liaoning, Shanghai, Jiangsu, Zhejiang, Fujian, Shandong, and Guangdong, was low. There is little difference in the efficiencies of the provinces within the eastern region. The efficiency values of Jilin and Heilongjiang were higher than those of the other provinces, reaching 0.532 and 0.519 , respectively. Compared with the eastern region, the situation of the toll road operations in the central region is better. The efficiency values of Inner Mongolia, Guangxi, Qinghai, and Xinjiang were as high as $0.979,0.758,0.826$, and 0.887 , respectively, but other provinces in the western region had normal efficiency values.

Figure 3 displays the sizes and changing trends of the operational efficiency in the three regions. The figure reveals that the regional differences between the east and west are striking. The average values of the operational efficiency of the provinces in the eastern region, central region, and western region were $0.202,0.372$, and 0.537 , respectively. The toll road operations in the west were the most efficient, those in the central region were the second most efficient, and those in the eastern region were the least efficient. Moreover, there was no large fluctuation in the operational efficiency trends, and all the regions showed similar trends. The operational efficiency decreased from 2014 to 2015 and rebounded from 2015 to 2016 . There were similar periodic changes in 2016-2018 and in 2014-2016. These changes were very slight, so there was no significant increase or decrease in the efficiency of toll roads.

4.2. Regression Results. To investigate the effect of concession on the operational efficiency of toll roads in Mainland China, this research established the regression model as shown in formula (4):

$$
\begin{aligned}
\text { Efficiency }_{i t}= & \beta_{0}+\beta_{1} \text { Concession }_{i t}+\beta_{2} \mathrm{IE}_{i t}+\beta_{3} \text { PGDP }_{i t} \\
& +\beta_{4} \text { Competition }_{i t}+\beta_{5} \text { Scale }_{i t}+\mu_{i}+\varepsilon_{i t},
\end{aligned}
$$

where Efficiency is the operational efficiency of the toll roads in Mainland China. The independent variables are Concession, IE, PGDP, Competition, and Scale.

Considering that there are significant differences in the operating efficiency of the toll roads among the three regions, it is necessary to study the relationship between concession and operational efficiency in three regions separately. Therefore, we used the Stata 12 software to calculate formula (4) for the different samples, including the national, eastern region, central region, and western region samples. The results of the regression are shown in Table 5.

As the main explanatory variable that concerns us, concession had no significant effect on the operational efficiency of toll roads for the national average data or the central region. This result was consistent with Hypotheses 1 and 2 . In the eastern region, the influence of concession on operational efficiency was significantly positive; that is, 
TABLE 4: Results of operational efficiency of toll roads.

\begin{tabular}{|c|c|c|c|c|c|c|c|}
\hline Region & Province & 2014 & 2015 & 2016 & 2017 & 2018 & Average \\
\hline \multirow{11}{*}{ Eastern } & Beijing & 0.068 & 0.059 & 0.071 & 0.054 & 0.063 & 0.063 \\
\hline & Tianjin & 0.200 & 0.101 & 0.190 & 0.155 & 0.148 & .159 \\
\hline & Hebei & 0.232 & 0.167 & 0.243 & 0.195 & 0.200 & 0.207 \\
\hline & Liaoning & 0.287 & 0.223 & 0.354 & 0.272 & 0.333 & 0.294 \\
\hline & Shanghai & 0.113 & 0.079 & 0.080 & 0.089 & 0.098 & 0.092 \\
\hline & Jiangsu & 0.237 & 0.212 & 0.280 & 0.210 & 0.202 & 0.228 \\
\hline & Zhejia & 0.194 & 0.162 & 0.244 & 0.202 & 0.212 & 0.203 \\
\hline & Fuji & 0.316 & 0.324 & 0.412 & 0.305 & 0.370 & 0.345 \\
\hline & Shandong & 0.294 & 0.210 & 0.295 & 0.219 & 0.235 & 0.251 \\
\hline & Guan & 0.187 & 0.157 & 0.231 & 0.157 & 0.174 & 0.181 \\
\hline & $\begin{array}{l}\text { Regional } \\
\text { average }\end{array}$ & 0.213 & 0.169 & 0.240 & 0.186 & 0.204 & 0.202 \\
\hline \multirow{9}{*}{ Central } & & 0.394 & 0.198 & 0.256 & 0.226 & 0.275 & 0.270 \\
\hline & & 568 & 0.386 & 0.647 & 0.453 & 0.606 & 532 \\
\hline & Heilon & 516 & 0.569 & 0.522 & 0.420 & 0.567 & 519 \\
\hline & An & 0.424 & 0.311 & 0.479 & 0.380 & 0.388 & 396 \\
\hline & Jian & 0.211 & 0.238 & 0.250 & 0.242 & 0.237 & .236 \\
\hline & & 0.313 & 0.206 & 0.395 & 0.272 & 0.296 & 0.296 \\
\hline & & 322 & 0.259 & 0.36 & 0.278 & 0.417 & 0.327 \\
\hline & Hunan & 0.407 & 0.283 & 0.433 & 0.361 & 0.501 & 0.397 \\
\hline & $\begin{array}{c}\text { Regional } \\
\text { average }\end{array}$ & 0.394 & 0.306 & 0.418 & 0.329 & 0.411 & 0.372 \\
\hline \multirow{12}{*}{ Western } & Inner Mongolia & 0.894 & 1.000 & 1.000 & 1.000 & 1.000 & 0.979 \\
\hline & Guangxi & 1.000 & 0.645 & 1.000 & 0.530 & 0.613 & 0.758 \\
\hline & Chongqing & 0.279 & 0.186 & 0.260 & 0.228 & 0.259 & 0.242 \\
\hline & Sichuan & 0.358 & 0.266 & 0.368 & 0.232 & 0.244 & 0.294 \\
\hline & Guizhou & 0.436 & 0.325 & 0.470 & 0.446 & 0.459 & 0.427 \\
\hline & Yunnan & 0.320 & 0.203 & 0.362 & 0.369 & 0.438 & 0.338 \\
\hline & Shaanxi & 0.275 & 0.205 & 0.259 & 0.187 & 0.230 & 0.231 \\
\hline & Gansu & 0.641 & 0.454 & 0.611 & 0.346 & 0.307 & 0.472 \\
\hline & Qinghai & 0.844 & 0.799 & 1.000 & 0.723 & 0.763 & 0.826 \\
\hline & Ningxia & 0.548 & 0.358 & 0.584 & 0.381 & 0.418 & 0.458 \\
\hline & Xinjiang & 1.000 & 0.666 & 0.770 & 1.000 & 1.000 & 0.887 \\
\hline & $\begin{array}{l}\text { Regional } \\
\text { average }\end{array}$ & 0.599 & 0.464 & 0.608 & 0.495 & 0.521 & 0.537 \\
\hline \multicolumn{2}{|c|}{ National average } & 0.410 & 0.319 & 0.428 & 0.342 & 0.381 & 0.376 \\
\hline
\end{tabular}

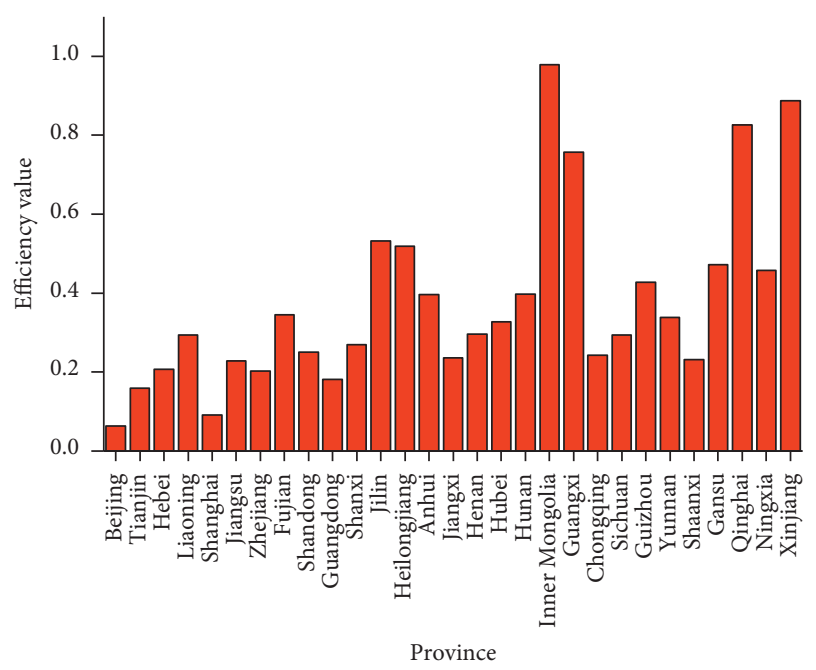

Figure 2: Average operational efficiency of the toll roads in 29 provinces from 2014 to 2018 .

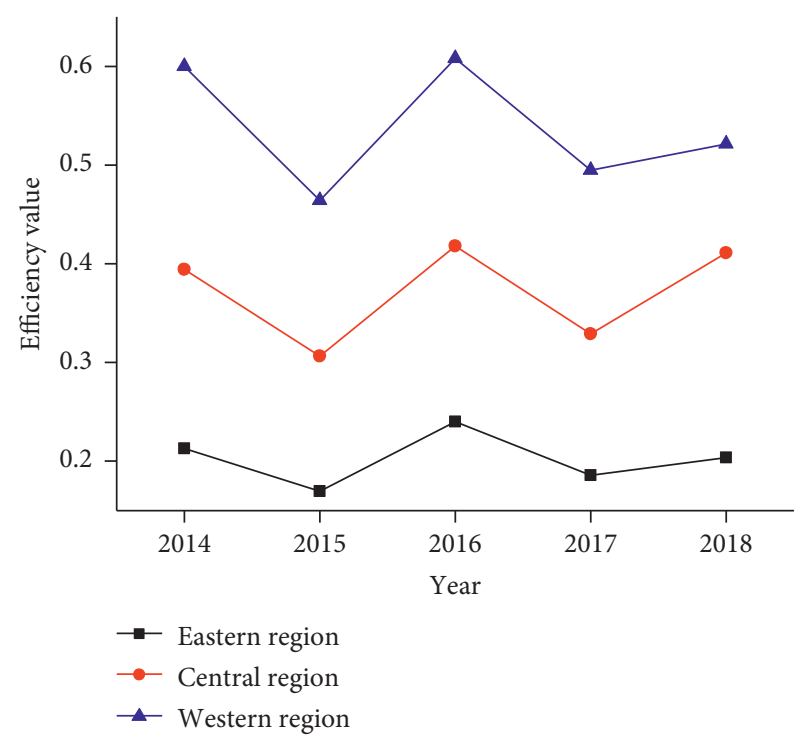

FIGURE 3: Changing trends of the operational efficiency of the toll roads in the three regions.

concession can improve the operational efficiency of toll roads. When the proportion of the mileage of toll roads operated by private firms is increased by $1 \%$, the efficiency will improve by 0.059 . However, concession had a significant negative impact on the operational efficiency in the western region.

The institutional environment was negatively related to the operational efficiency in the eastern provinces. The mean of the institutional environment in the eastern provinces was 9.072, and thus, these provinces have sound public participation mechanisms. Operators needed to invest more in terms of maintenance and operations to meet people's growing requirements for the traffic capacity and service quality of toll roads, especially during holidays or in extreme weather. The institutional environment did not play a significant role in the central and western provinces. The possible reason is that the institutional environment did not affect the operations until a certain threshold was reached [58].

GDP per capita played an important role in improving the operational efficiency for the national average, and this effect was mainly reflected in the western provinces. In the western region, the level of economic development was still a limiting factor for toll road operations. As the economy develops, the operational efficiency will improve through management innovations and technological progress. Economic development no longer affected the operational efficiency of toll roads in the eastern and central regions.

Competition was negatively correlated with the operational efficiency of the toll roads in the eastern and western provinces. The construction of freeways and railways has led to great achievements in Mainland China, and their scale has reached or is moderately ahead of the scale of the regional economic development [62]. Railway transportation and toll roads have formed a competitive relationship. The greater the railway mileage, the greater the investments in toll road 
TABLE 5: Regression results.

\begin{tabular}{lcccc}
\hline Variable & National & Eastern & Central & Western \\
\hline Concession & $-0.0217(0.0668)$ & $0.0594^{*}(0.0306)$ & $0.0396(0.132)$ & $-0.309^{*}(0.165)$ \\
IE & $-0.0458^{* * *}(0.0177)$ & $-0.0244^{*}(0.0147)$ & $-0.00343(0.0380)$ & $0.00424(0.0393)$ \\
PGDP & $3.83 e-06^{* *}(1.54 e-06)$ & $1.18 e-06(1.02 e-06)$ & $5.85 e-06(3.99 e-06)$ & $7.62 e-06^{* *}(3.39 e-06)$ \\
Competition & $-9.078^{* * *}(2.490)$ & $-3.361^{* * *}(1.134)$ & $4.845(6.534)$ & $-30.68^{* * *}(10.76)$ \\
Scale & $2.181(1.815)$ & $0.403(0.993)$ & $-10.08^{* *}(4.129)$ & $9.166^{* *}(3.702)$ \\
Constant & $0.667^{* * *}(0.0930)$ & $0.416^{* * *}(0.0980)$ & $0.294^{*}(0.172)$ & $0.538^{* * *}(0.170)$ \\
sigma_u & $0.151^{* * *}(0.0286)$ & $0.0557^{* * *}(0.0165)$ & $0.0433^{* *}(0.0183)$ & $0.172^{* * *}(0.0419)$ \\
sigma_e & $0.0873^{* * *}(0.00662)$ & $0.0322^{* * *}(0.00383)$ & $0.0713^{* * *}(0.00907)$ & $0.125^{* * *}(0.0155)$ \\
\hline
\end{tabular}

Note. Standard errors in parentheses, ${ }^{* * *} p<0.01,{ }^{* *} p<0.05$, and ${ }^{*} p<0.1$.

operations, which also proves the positive impact of competition on service quality and efficiency.

The scale was negatively correlated with operational efficiency in the central provinces, but it significantly promoted the operational efficiency in the western region. Consequently, scale had no significant effect on the operational efficiency of toll roads for the national average. The effect of scale on operational efficiency showed that the central provinces were in the stage of diminishing returns to scale, while the western regions were in the stage of increasing returns to scale. The scale of the eastern provinces was moderate. To further improve their operational efficiency, the western provinces can further increase the scale of their toll roads.

\section{Discussion}

5.1. Discussion of Operational Efficiency. The results showed that toll road operations were inefficient, which is consistent with the conclusion of Wei et al. [21]. It should be noted that there is a significant difference in the efficiency among the eastern, central, and western regions. The toll road operations in the western region were the most efficient, those in the central region were the second most efficient, and those in the eastern region were the least efficient. Conversely, $\mathrm{Xu}$ et al. adopted tolls as the output and used the same inputs as this research, and their results showed that the operation in the eastern region was the most efficient of the three regions [62]. The differences between their results and our results can be attributed to the output. Given their economics and traffic flow, the eastern provinces gained more road tolls and achieved a higher operational efficiency than the western provinces.

The possible reason for this difference is that, for the same toll road, compared with the western region, the eastern provinces had to invest more in operations and maintenance because their toll roads were badly worn by the larger traffic flow. However, regardless of the efficiency, the purpose of this research is to investigate the impact of concession on the operational efficiency of toll roads in Mainland China according to cost savings. In view of the differences in the efficiency among the provinces in the different regions, we formulated the regression model based on different samples.

5.2. Discussion of the Effect of Concession. The transformation of the operating system had no effect on the efficiency of toll roads nationally. The results of the regional regression showed that concession can significantly improve the operational efficiency of toll roads in the eastern region; however, the effect is negative in the western region. Compared with the existing assessment of the impact of private participation on the public service provision performance [44], the results in this research are within our prediction. It is worth noting that concession has failed to meet the expectations of governments and scholars. The uncertainty of the effect of concession should be considered.

The effect of concession depends on the competitive mechanisms [54, 63], and a higher degree of marketization contributes to introducing competitive mechanisms in both the concession stage and the toll road operations stage. In the eastern provinces, governments can select the better option to operate toll roads. Moreover, operators will continuously improve their management abilities and reduce operating costs to maintain competitive advantages. However, competitors may gain concession rights via rent-seeking in the western provinces. Monopoly operators prefer requesting government subsidies to save operating costs. Therefore, concession increases management and maintenance expenditures and reduces operational efficiency in the western provinces.

\section{Conclusions and Policy Implications}

With PPPs becoming the main system for the provision of infrastructure, concession has become the operating mode of toll roads that the government and society strongly advocate. To objectively compare the efficiency of concession and the traditional government provision system, we evaluated the operational efficiency of toll roads and analysed the impact of the transformation from government operations to concession on the operational efficiency. The results show the following. First, there were strong possibilities for cost savings in terms of maintenance and operations management expenditures. The difference in the operational efficiency among the eastern, central, and western regions was significant. Second, the effects of concession on operational efficiency were also different. Nationally, the transformation of the operating mode did not affect the efficiency of toll roads. At the regional level, concession can significantly improve the operational efficiency of toll roads in the eastern region. However, the effect was significantly negative in the western region. In summary, concession was not as effective as people expected. In other words, concession is a mode of 
provision that does not necessarily improve the provision efficiency of infrastructure. Therefore, the promotion of concession and PPPs for toll roads and other public service areas should be treated with caution.

The evidence from this research leads to the following policy implications.

First, the government should observe that toll road operations are inefficient and there is considerable room for cost savings. The operators must improve their operational efficiency and payment abilities rather than depending on government subsidies and loans, which can eventually improve the endogenous power to sustainably develop toll roads.

Second, applying an appropriate operating mode in each province is particularly beneficial for improving the operational efficiency. The eastern provinces can steadily promote concession and license the conditional highways to the strongest operators. The central provinces should actively learn from the eastern provinces and explore their own concession modes. The western provinces should be cautious about concession. As for the toll roads in the western provinces, public sector operations may be the best choice in the present stage, which can also help to achieve economies of scale.

Finally, the government should dedicate itself to refining the implementation environment of PPPs. Introducing a competitive mechanism is the essence of toll road concession, and it contributes to choosing the best mode to operate toll roads. Concessionary operators are incentivized by the government to provide the best service at the lowest cost, which eventually takes advantage of private participation to improve the operational efficiency of toll roads.

This research focused on the operational efficiency of toll roads in terms of cost savings and showed that the efficiency advantages of concession were not given full play. Service quality is also an important aspect of toll road operations. The limitation of this research is that we examined the effect of concession without considering the service quality of toll roads. In further research, more diverse performance indicators of toll roads, such as driver satisfaction, degree of greening, and pavement maintenance quality, will be integrated into the performance assessment framework.

\section{Data Availability}

The data used to support the findings of this study are available from the corresponding author upon request.

\section{Conflicts of Interest}

The authors declare that there are no conflicts of interest regarding the publication of this paper.

\section{Acknowledgments}

This work was supported by the MOE (Ministry of Education in China) Layout Foundation of Humanities and Social Sciences (Grant no. 19YJA790097) and the Fundamental Research Funds for the Central Universities of China (Grant no. 300102238639).

\section{References}

[1] J. Tan and J. Z. Zhao, "The rise of public-private partnerships in china: an effective financing approach for infrastructure investment?" Public Administration Review, vol. 79, no. 4, pp. 514-518, 2019.

[2] L. Ma, J. Li, R. Jin, and Y. Ke, "A holistic review of publicprivate partnership literature published between 2008 and 2018," Advances in Civil Engineering, vol. 2019, Article ID 7094653, 18 pages, 2019.

[3] A. Mostafavi, D. Abraham, and A. Vives, "Exploratory analysis of public perceptions of innovative financing for infrastructure systems in the U.S," Transportation Research Part A: Policy and Practice, vol. 70, pp. 10-23, 2014.

[4] M. Percoco, "Quality of institutions and private participation in transport infrastructure investment: evidence from developing countries," Transportation Research Part A: Policy and Practice, vol. 70, pp. 50-58, 2014.

[5] M. R. Pryn, Y. Cornet, and K. B. Salling, "Applying sustainability theory to transport infrastructure assessment using a multiplicative ahp decision support model," Transport, vol. 30, no. 3, pp. 330-341, 2015.

[6] G. Hodge, Privatization: An International Review of Performance, Routledge, Abingdon, UK, 2018.

[7] Y. Jing and E. S. Savas, "Managing collaborative service delivery: comparing China and the United States," Public Administration Review, vol. 69, no. s1, pp. S101-S107, 2009.

[8] D. Penyalver, M. Turró, and J. B. Williamson, "Measuring the value for money of transport infrastructure procurement; an intergenerational approach," Transportation Research Part A: Policy and Practice, vol. 119, pp. 238-254, 2019.

[9] L. Athias and S. Saussier, "Are public private partnerships that rigid? and why? evidence from price provisions in french toll road concession contracts," Transportation Research Part a: Policy and Practice, vol. 111, pp. 174-186, 2018.

[10] S. Letand and O. Smirnova, "Reassessing privatization strategies 25 years later: revisiting perry and babitsky's comparative performance study of urban bus transit services," Public Administration Review, vol. 69, no. 5, pp. 855-867, 2009.

[11] Y. Zhang, Z. Feng, and S. Zhang, "The effects of concession period structures on BOT road contracts," Transportation Research Part A: Policy and Practice, vol. 107, pp. 106-125, 2018.

[12] "Suggestions on the implementation of the mode of cooperation between government and social capital in the field of toll roads," June 2020, http://www.gov.cn/zhengce/2016-05/ 22/content_5075680.htm.

[13] "National statistics summary table of toll road in 2018," March 2020, http://xxgk.mot.gov.cn/jigou/glj/201908/t20190829_ 3243792.html?agt=298.

[14] H. Xu, R. Jia, and Y. Zheng, "Structural reform of supply side for transport infrastructure," Journal of Chang'an University(Social Science Edition), vol. 21, no. 1, pp. 16-23, 2019.

[15] Q. Li, "Harm and breaking path of the administrative monopoly for tolling road," Highway, vol. 60, no. 3, pp. 125-130, 2015.

[16] H. Xu, P. Bai, and J. Wang, "Estimation of rant dissipation based on administrative monopoly in toll road industry and corresponding eliminating strategies," On Economic Problems, vol. 12, pp. 30-36, 2016.

[17] J. Wang and H. Xu, "Research on scale and efficiency in infrastructure industry based on efficient competition," 
Journal of Northwest University (Philosophy and Social Sciences Edition), vol. 43, no. 1, pp. 121-125, 2013.

[18] Y. Zhu, "Quantitative analysis of the administrative monopoly and efficiency of toll road industry," Statistics \& Decision, vol. 11, pp. 104-107, 2015.

[19] H. Xu and P. Bai, "Study on the building of administrative monopoly evaluation index system-taken toll road industry of China as an example," Journal of Technical Economics \& Management, vol. 8, pp. 3-7, 2015.

[20] B. Wang and Q. Li, "Performance evaluation and dynamic analysis of listed companies in the expressway industry," Enterprise Economy, no. 8, pp. 175-179, 2014.

[21] X. Wei, H. Xu, B. Zhang, and J. Li, "Infrastructure operation efficiency and influential factors in developing countries: evidence from China," Sustainability, vol. 11, no. 3, p. 655, 2019.

[22] G. Hodge, C. Greve, and M. Biygautane, "Do PPP's work? what and how have we been learning so far?" Public Management Review, vol. 20, no. 8, pp. 1105-1121, 2018.

[23] S. Jeffares, H. Sullivan, and T. Bovaird, "Beyond the contract: the challenge of evaluating the performance (s) of publicprivate partnerships," in Rethinking Public-Private Partnerships: Strategies for Turbulent Times, G. Hodge and C. Greve, Eds., pp. 166-187, Routledge, Abingdon, UK, 2013.

[24] T. Jie, "The effectiveness of public-private partnership (PPP) as a financing tool for local governments," $\mathrm{Ph}$. D. thesis, Zhejing university, Hangzhou, China, 2020.

[25] W. Shouqing, Z. Bo, C. Jiaxu, and N. Yunshi, "Study on the influence of government behavior on PPP performance," Soft Science, vol. 34, no. 3, pp. 1-5, 2020.

[26] E. M. Engel, R. D. Fischer, and A. Galetovic, "The economics of infrastructure finance: public-private partnerships versus public provision," EIB Papers, vol. 15, no. 1, pp. 40-69, 2010.

[27] D. Makovšek and M. Moszoro, "Risk pricing inefficiency in public-private partnerships," Transport Reviews, vol. 38, no. 3, pp. 298-321, 2018.

[28] "Operational guidelines for performance management of public-private partnership (PPP) projects," September 2020, http://www.gov.cn/zhengce/zhengceku/2020-03/31/content_ 5497463.htm.

[29] G. Hodge and C. Greve, "Theorizing public-private partnership success: a market-based alternative to government," in Proceedings of the Public Management Research Conference at Syracuse University, Syracuse, NY, USA, June 2011.

[30] H. Hodge and C. Greve, "Public-private partnerships: an international performance review," Public Administration Review, vol. 67, no. 3, pp. 545-558, 2007.

[31] Z. Chen, N. Daito, and J. L. Gifford, "Data review of transportation infrastructure public-private partnership: a metaanalysis," Transport Reviews, vol. 36, no. 2, pp. 228-250, 2016.

[32] C. Cai, "Institutional environments, institutional performance and public service marketization: an analytic framework," Management World, no. 4, pp. 52-69+80+187-188, 2016.

[33] O. M. Rouhani, R. R. Geddes, H. O. Gao, and G. Bel, "Social welfare analysis of investment public-private partnership approaches for transportation projects," Transportation Research Part A: Policy and Practice, vol. 88, pp. 86-103, 2016.

[34] H. Wang, W. Xiong, G. Wu, and D. Zhu, "Public-private partnership in public administration discipline: a literature review," Public Management Review, vol. 20, no. 2, pp. 293-316, 2018.

[35] O. Helby Petersen, "Evaluating the costs, quality, and value for money of infrastructure public-private partnerships: a systematic literature review," Annals of Public and Cooperative Economics, vol. 90, no. 2, pp. 227-244, 2019.

[36] Q. Shan and R. Chaohe, "China's transportation infrastructure supply and demand mismatch and public-private cooperation dilemma and its countermeasures-based on the perspective of supply-side structural reform," Social Sciences in Yunnan, no. 4, pp. 64-69, 2017.

[37] J. Besant-Jones, A. Estache, G. K. Ingram et al., World Development Report 1994: Infrastructure for Development, The World Bank, Washington, DC, USA, 1994.

[38] J. Rosell and A. Saz-Carranza, "Determinants of public-private partnership policies," Public Management Review, vol. 22, no. 8, pp. 1171-1190, 2020.

[39] A. D. Chasey, W. E. Maddex, and A. Bansal, "Comparison of public-private partnerships and traditional procurement methods in North American highway construction," Transportation Research Record: Journal of the Transportation Research Board, vol. 2268, no. 1, pp. 26-32, 2012.

[40] P. Raisbeck, C. Duffield, and M. Xu, "Comparative performance of PPPs and traditional procurement in Australia," Construction Management and Economics, vol. 28, no. 4, pp. 345-359, 2010.

[41] B. Vis, "The comparative advantages of fsQCA and regression analysis for moderately large- $N$ analyses," Sociological Methods \& Research, vol. 41, no. 1, pp. 168-198, 2012.

[42] F. Blanc-Brude, H. Goldsmith, and T. Valila, "Ex ante construction costs in the european road sector: a comparison of public-private partnerships and traditional public procurement," EIB Economic and Finance Report No. 2006/1, 2006.

[43] H. Xu, Highway Economics, China Communications Press, Beijing, China, 2008.

[44] S. Domberger and P. Jensen, "Contracting out by the public sector: theory, evidence, prospects," Oxford Review of Economic Policy, vol. 13, no. 4, pp. 67-78, 1997.

[45] Y. Guoliang, G. Wenbin, and Z. Haijun, "A review of data envelopment analysis mothods (DEA)," Journal of Systems Engineering, vol. 28, no. 6, pp. 840-860, 2013.

[46] M. Asmild, J. C. Paradi, V. Aggarwall, and C. Schaffnit, "Combining DEA window analysis with the malmquist index approach in a study of the Canadian banking industry," Journal of Productivity Analysis, vol. 21, no. 1, pp. 67-89, 2004.

[47] K. Tone, "A slacks-based measure of efficiency in data envelopment analysis," European Journal of Operational Research, vol. 130, no. 3, pp. 498-509, 2001.

[48] C. Qiang, Advanced Econometrics and STATA Applications, Higher Education Press, Beijing, China, 2010.

[49] S. Lindhard and J. K. Larsen, "Identifying the key process factors affecting project performance," Engineering, Construction and Architectural Management, vol. 23, no. 5, pp. 657-673, 2016.

[50] A. P. C. Chan, D. Scott, and A. P. L. Chan, "Factors affecting the success of a construction project," Journal of Construction Engineering and Management, vol. 130, no. 1, pp. 153-155, 2004.

[51] K. C. Iyer and K. N. Jha, "Factors affecting cost performance: evidence from Indian construction projects," International Journal of Project Management, vol. 23, no. 4, pp. 283-295, 2005.

[52] D. K. H. Chua, Y. C. Kog, and P. K. Loh, "Critical success factors for different project objectives," Journal of Construction Engineering and Management, vol. 125, no. 3, pp. 142150, 1999. 
[53] Y. Yilin and D. Yaling, Improvement of Public Project Management Performance Based on Governance, Science Press, Beijing, China, 2010.

[54] A. A. Ahmadabadi and G. Heravi, "The effect of critical success factors on project success in public-private partnership projects: a case study of highway projects in Iran," Transport Policy, vol. 73, pp. 152-161, 2019.

[55] S. Zhang, Y. Gao, Z. Feng, and W. Sun, "PPP application in infrastructure development in China: institutional analysis and implications," International Journal of Project Management, vol. 33, no. 3, pp. 497-509, 2015.

[56] W. Belassi and O. I. Tukel, "A new framework for determining critical success/failure factors in projects," International Journal of Project Management, vol. 14, no. 3, pp. 141-151, 1996.

[57] X. Dong, Y. Du, and X. Wu, "Efficiency advantages and incentive mechanism of PPPs: a qualitative comparative analysis under the Chinese scenario," Advances in Civil Engineering, vol. 2018, Article ID 6045064, 11 pages, 2018.

[58] J. Wei, P. Ge, and J. Wang, "Environment, institution dependence and enterprise TFP," Statistical Research, vol. 34, no. 5, pp. 38-48, 2017.

[59] Z. Xiao and J. S. L. Lam, "The impact of institutional conditions on willingness to take contractual risk in port publicprivate partnerships of developing countries," Transportation Research Part A: Policy and Practice, vol. 133, pp. 12-26, 2020.

[60] X. Wang, G. Fan, and L. Hu, 2018 Index of Marketization of China's Province, pp. 201-230, Social Sciences Academic Press, Beijing, China, 2019.

[61] K. Z. Zhou, G. Y. Gao, and H. Zhao, "State ownership and firm innovation in China: an integrated view of institutional and efficiency logics," Administrative Science Quarterly, vol. 62, no. 2, pp. 375-404, 2016.

[62] H. Xu, Y. Wang, and R. Jia, "Research on efficiency of toll road dual-track operation system based on three stage DEA and Tobit regression model," China Journal of Highway and Transport, vol. 30, no. 9, pp. 125-132, 2017.

[63] Z. Xiao and J. S. L. Lam, "Willingness to take contractual risk in port public-private partnerships under economic volatility: the role of institutional environment in emerging economies," Transport Policy, vol. 81, pp. 106-116, 2019. 